\title{
Aurikuloplasti (Serial Kasus) pada Mikrotia Post Graft dan Rekonstruksi Tahap 1
}

\author{
Fanny Yudhiono, Shinta Fitri Boesoerie \\ Departemen Ilmu Telinga Hidung Tenggorokan Kepala Leher, Fakultas Kedokteran, Universitas Padjadjaran/ \\ Rumah Sakit Umum Dr. Hasan Sadikin, Bandung, Indonesia
}

\begin{abstract}
Abstrak
Mikrotia didefinisikan sebagai malformasi daun telinga yang memperlihatkan kelainan bentuk ringan sampai berat dengan ukuran kecil sampai tidak terbentuk sama sekali (anotia). Saat ini penggunaan tandur tulang rawan iga autologus masih menjadi baku emas untuk rekonstruksi mikrotia. Prosedur ini diketahui memiliki komplikasi yang sangat jarang, meskipun begitu masih terdapat literatur yang melaporkan terdapat komplikasi berupa infeksi dan reaksi penolakan tubuh pada prosedur tersebut. Kasus ini diajukan untuk menunjukan keberhasilan tahap pertama rekonstruksi mikrotia dilihat dari tanda infeksi dan reaksi penolakan tubuh terhadap tandur tulang rawan iga. Studi ini merupakan suatu laporan kasus mengenai rekonstruksi telinga dengan prosedur aurikuloplasti tahap 1 pada wanita 17 tahun dengan mikrotia bilateral derajat 3 dan laki laki usia 15 tahun dengan mikrotia unilateral derajat 3 di Rumah Sakit Dr. Hasan Sadikin tahun 2016. Evaluasi lokasi rekonstruksi pada saat kedua pasien pulang menunjukkan tidak adanya tanda infeksi maupun reaksi penolakan tubuh. Penggunaan tandur autologus masih mejadi pilihan utama dalam penatalaksaanaan operasi mikrotia. Prosedur yang tepat serta perawatan yang baik dapat mengurangi angka kejadian kejadian infeksi dan terhindar dari reaksi penolakan tubuh terhadap jaringan. Pada kasus ini toleransi telinga terhadap tekanan jangka panjang memiliki respon yang cukup baik.
\end{abstract}

Kata kunci : Aurikuloplasti, graft, mikrotia, rekonstruksi

\section{Auriculoplasty (Serial Cases) of Microtia After Grafting and Stage I Reconstruction}

\begin{abstract}
Microtia is a congenital deformity in which the external ear is underdeveloped from mild to severe grade. Nowadays, rib cartilage graft is still considered the gold standard for bilateral and unilateral microtia reconstruction. Complication rate is very low, nonetheless a small number of study still report infection and graft rejection as complication of auricoplasty. This case report aims to show the success first stage microtia reconstruction in terms of signs of infection and graft rejection. This study is a case report regarding ear reconstruction applying stage I auriculoplasty on a 17th years old girl with 3rd grade bilateral microtia and a 15th years old boy with 3rd grade unilateral microtia in Dr.Hasan Sadikin General Hospital in 2016. Final evaluation of reconstructed area exhibit no sign of infection nor graft rejection reaction. Autologous graft remains the best choice in microtia reconstruction surgery. Precise procedure and well handed care may reduce rate of infection and rejection reaction. In this case, ear tolerance respond to long term pressure is exemplary.
\end{abstract}

Keywords : Auriculoplasty, graft, microtia, reconstruction

\footnotetext{
Korespondensi:

Fanny Yudhiono, dr

Departemen Ilmu Telinga Hidung Tenggorokan Kepala Leher, Fakultas Kedokteran, Universitas Padjadjaran/

Rumah Sakit Umum Dr. Hasan Sadikin, Bandung, Indonesia

Jl. Pasteur No. 38, Kota Bandung, 40161

Mobile : 082115262556

Email : yudiono461@gmail.com
} 


\section{Pendahuluan}

Mikrotia terbentuk dari dua kata yaitu micro yang artinya kecil dan otia yang artinya telinga. Mikrotia adalah malformasi daun telinga yang memperlihatkan kelainan bentuk ringan sampai berat, dengan ukuran kecil sampai tidak terbentuk sama sekali (anotia). ${ }^{1,2}$

Kelainan kongenital ini terjadi akibat cacat pertumbuhan tulang rawan Meckel dari arkus brankialis I yang menyebabkan gangguan pertumbuhan pina. Kelainan ini sering kali diikuti dengan gangguan pertumbuhan telinga bagian tengah dengan akibat tuli konduksi. ${ }^{1,2}$

Kejadian pada lelaki lebih sering daripada perempuan. Angka kejadiannya adalah 1:7000 kelahiran dan lebih sering terjadi pada telinga kanan. Sekitar 90\% mengenai telinga unilateral dan $10 \%$ sisanya bilateral. ${ }^{1}$ Jumlahnya di Indonesia belum diketahui dengan pasti karena tidak pernah ada koleksi data sehubungan dengan mikrotia. Ras Asia lebih sering terkena daripada ras lainnya. ${ }^{1-5}$ Usia pasien menjadi pertimbangan operasi, minimal berumur 6-8 tahun. Pada usia ini kartilago tulang iga sudah cukup memadai untuk dibentuk sebagai rangka telinga dan telinga sisi normal telah mencapai pertumbuhan maksimal, sehingga dapat digunakan sebagai contoh rangka telinga. Pada usia ini daun telinga mecapai 80$90 \%$ ukuran dewasa. ${ }^{5,6,7}$ Menurut survei yang dilakukan di amerika sebanyak $91,3 \%$ prosedur tandur autologous untuk mikrotia masih digunakan. Meskipun angka komplikasi yang rendah, masih saja terdapat komplikasi pada prosedur ini. Penelitian systematic review yang dilakukan oleh Xiao Long dkk, angka komplikasi pada prosedur tandur autologous masih bervariasi berkisar 0-72,9\%. Dibandingkan survei yang dilakukan perhimpunan bedah di amerika sebanyak 13,58\%. Komplikasi tersebut berupa infeksi pada resipen dan hematoma. ${ }^{8}$

Laporan kasus ini bertujuan untuk menunjukan keberhasilan rekonstruksi mikrotia menggunakan metode tandur autologus tahap pertama dengan menunjukan komplikasi yang minimal di Departemen THT-KL Rumah Sakit Hasan Sadikin.

\section{Metode}

Studi ini merupakan suatu laporan kasus mengenai rekonstruksi pada dua pasien, satu dengan mikrotia bilateral dan lainnya unilateral dimana keduanya termasuk kedalam klasifikasi mikrotia derajat 3 . Kedua pasien berusia diatas 10 tahun sehingga sudah memenuhi indikasi dilakukan operasi rekonstruksi. Tidak terdapat kontraindikasi seperti kondisi tubuh yang tidak stabil untuk operasi maupun deformitas dinding dada. Pasien dan orangtua telah mendapatkan penjelasan mengenai komplikasi prosedur yang mungkin terjadi seperti pneumothorax, hasil yang secara estetik tidak sesuai harapan, perdarahan, infeksi serta reaksi penolakan tubuh, dan tetap setuju untuk menjalani prosedur. Proses pengambilan serta penyajian data dalam laporan kasus ini telah melalui proses penjelasan kepada dan persetujuan dari pasien serta mendapat persetujuan dari Komite Etik Rumah Sakit Hasan Sadikin.

\section{Laporan Kasus 1}

Seorang perempuan usia 17 tahun datang ke poliklinik THT-KL Rumah Sakit Hasan Sadikin Bandung dengan keluhan kedua telinga tidak tumbuh sempurna. Keluhan disertai dengan kurang dapat mendengar pada kedua telinga. Keluhan tidak disertai adanya telinga berdenging maupun riwayat keluar cairan dari telinga.

Pada pemeriksaan fisik didapatkan telinga kanan dan kiri khas seperti kacang. Telinga kiri tidak memiliki helix dan antihelix serta tragus tetapi memiliki lobules. Kanalis akustikus eksternus juga tidak didapatkan pada pasien ini. Telinga sebelah kanan tidak didapatkan helix dan antihelix tetapi lobules dan kanalis akustikus ekternus masih ada.

Dari pemeriksaan $C T$ Scan didapatkan mikrotia dengan kanalis akustikus eksternus tidak tervisualisasi serta kanalis akustikus internus tampak tertutup. Membran timpani kanan dan kiri tak tervisualisasi, tulang pendengaran tervisualisasi dengan baik, koklea dan kanalis semisirkularis tampak jelas. Dari pemeriksaan audiometri didapatkan bahwa telinga kanan mengalami gangguan dengar tipe konduktif derajat sedang, sedangkan telinga kiri mempunyai hasil audiometri gangguan dengar tipe konduktif derajat berat. Pasien menjalani aurikuloplasti tahap 1 pada telinga kiri tanggal 11 Oktober 2016. Tahap pertama prosedur adalah pengambilan tandur autologus sebagai dasar rangka telinga (framework) dari iga 6,7,8 sisi kiri. Iga yang sudah diambil kemudian dibentuk sesuai pola telinga $\mathrm{ibu}$ pasien. Prosedur dilanjutkan dengan penanaman rangka telinga pada daerah retroaurikuler telinga kiri dan dilanjutkan transposisi lobul telinga. Paska operasi, pasien dirawat selama 5 hari untuk evaluasi graft yang ditanam pada retroaurikuler (seperti hematoma, tanda-tanda nekrosis, tandatanda ekstrusi dari rangka telinga). Tidak terdapat tanda infeksi maupun reaksi penolakan tubuh pada lokasi rekonstruksi saat pasien pulang. 

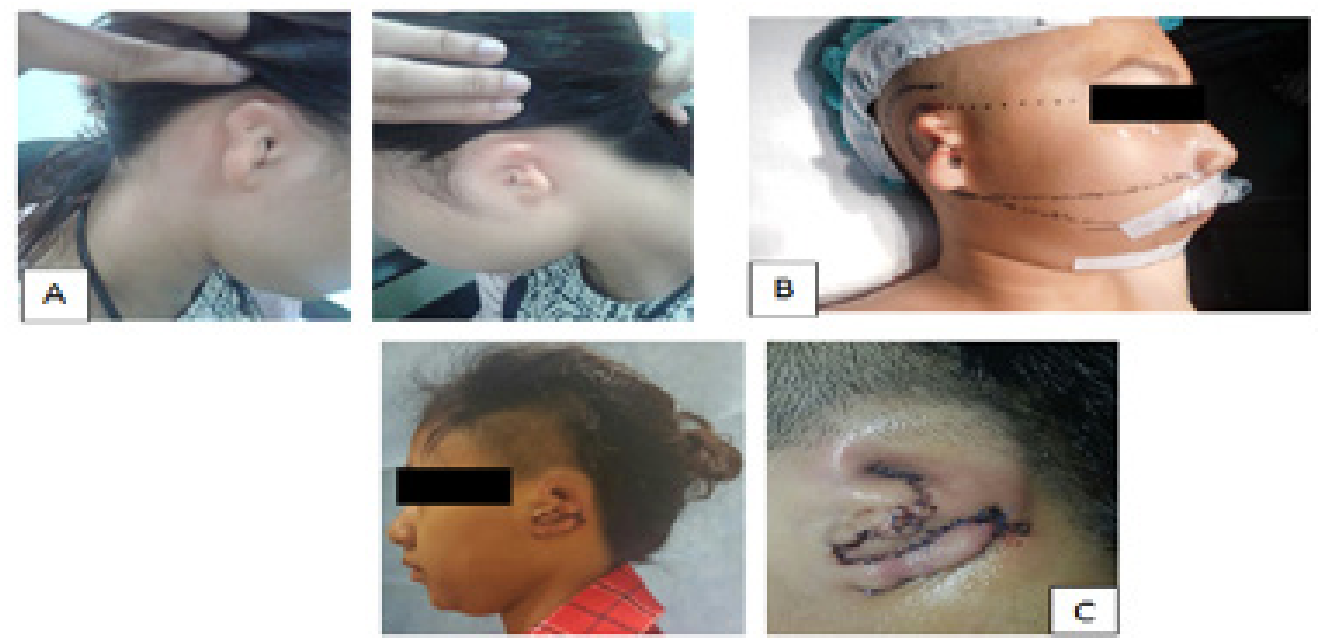

Gambar 1 Foto Klinis pasien (A) Mikrotia derajat 3 kanan dan kiri

(B) Foto Klinis sesaat sebelum operasi (C) Foto klinis sesudah operasi hari ke VII
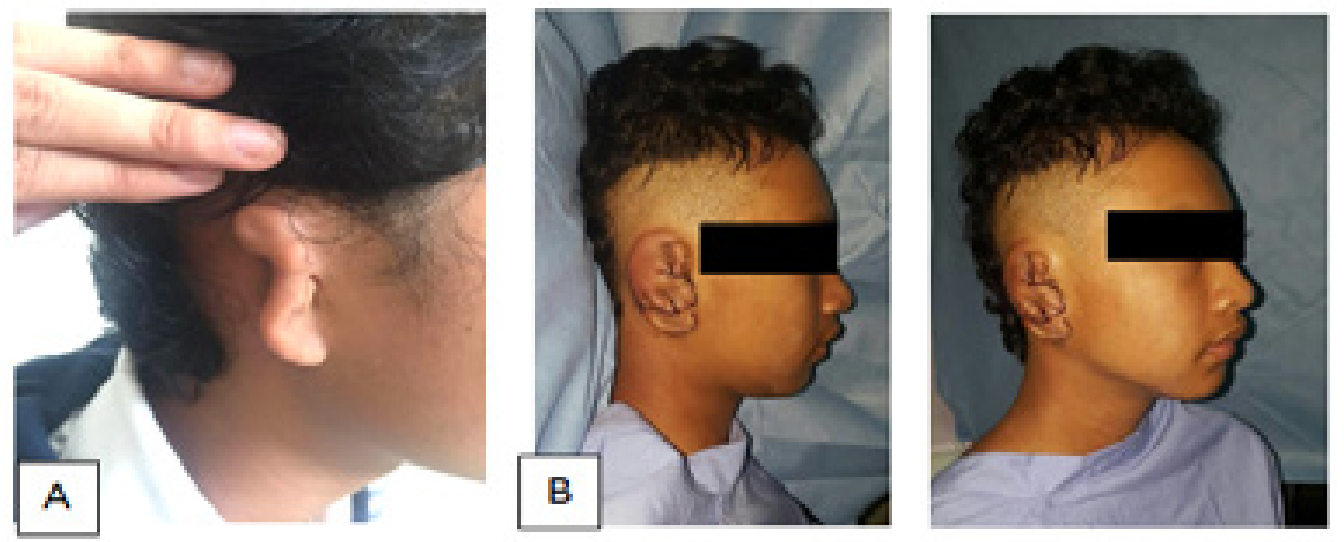

\section{Gambar 2 Foto Klinis (A) Sebelum Operasi (B) Sesudah Operasi}

\section{Laporan Kasus 2}

Seorang laki-laki berusia 15 tahun datang dengan keluhan telinga kanan tampak kecil dan tidak tumbuh dengan sempurna. Keluhan disertai dengan adanya gangguan pendengaran serta adanya telinga berdenging. Keluhan tidak disertai adanya riwayat keluar cairan dari telinga.

Pada pemeriksaan fisik didapatkan telinga kanan khas seperti kacang tidak memiliki helix dan antihelix serta tragus, tetapi memiliki lobules, kanalis akustikus eksternus juga tidak didapatkan pada pasien ini. Telinga sebelah kiri didapatkan helix, antihelix, lobules dan tragus serta kanalis akustikus ekternus dalam batas normal.

Pemeriksaan $C T$ Scan mastoid didapatkan mikrotia dengan kanalis akustikus eksternus tidak tervisualisasi dan kanalis akustikus internus tampak tertutup. Membran timpani kanan dan kiri tak tervisualisasi, tulang pendengaran ter $\neg$ visualisasi dengan baik, koklea dan kanalis semisirkularis tampak jelas. Hasil audiometri telinga sebelah kanan menunjukan adanya gangguan pendengaran tipe konduktif derajat berat. Telinga kiri didapatkan dalam batas normal. Pasien menjalani aurikuloplasti tahap 1 pada telinga kanan tanggal 20 September 2016. Tahap pertama prosedur adalah pengambilan tandur autologus sebagai dasar rangka telinga (framework) dari iga 5, 6, 7, dan 8 sisi kanan. Iga yang sudah diambil kemudian dibentuk sesuai pola telinga ibu pasien. Prosedur dilanjutkan dengan penanaman rangka telinga pada daerah retroaurikuler telinga kanan dan dilanjut $\neg$ kan transposisi lobul telinga. Paska operasi, pasien dirawat selama 5 hari untuk evaluasi graft yang ditanam pada retroaurikuler (seperti hematoma, tanda-tanda nekrosis, tanda-tanda ekstrusi dari rangka telinga). Tidak terdapat tanda infeksi maupun reaksi penolakan tubuh pada lokasi rekonstruksi saat pasien pulang. 


\section{Pembahasan}

Mikrotia merupakan suatu penyakit deformitas kraniofasia serius yang sering terjadi. Insidensinya berkisar antara 0,81-3,06 per 10.000 kelahiran di Cina. ${ }^{3}$ Pada serial kasus ini diketahui pasien berjenis kelamin perempuan dan lakilaki. Beberapa literatur menyebutkan insiden mikrotia pada anak laki-laki sekitar 1,5 kali lebih sering dari anak perempuan. Namun di Cina jenis kelamin tak mempengaruhi distribusi kejadian mikrotia. Mikrotia bilateral prevalensinya sekitar $10 \%$ atau sekitar $79-93 \%$ kasus pada mikrotia unilateral. ${ }^{3,8}$

Dalam penatalaksanannya prosedur aurikuloplasti merupakan terapi definitif pada keadaan ini. Beberapa sumber menyatakan hal berbeda mengenai usia ideal prosedur aurikuloplasti ini dilaksanakan tergantung teknik yang digunakan. Dengan metode Brent prosedur aurikuloplasti dapat dilakukan pada usia 6-8 tahun, dimana kartilago tulang iga sudah cukup memadai untuk dibentuk sebagai rangka telinga dan telinga sisi normal telah mencapai pertumbuhan maksimal sehingga dapat digunakan sebagai contoh rangka telinga. Pada usia ini besarnya kartilago iga yang akan diambil sebagai donor dan pertimbangan perkembangan telinga kontralateral maksimal mencapai $85 \%$ ukuran panjang dan 95\% ukuran lebar pada usia 6 tahun. Penggunaan metode Nagata, di sisi lain, memerlukan jumlah tulang rawan yang lebih banyak yaitu dari iga $6-9$ ipsilateral. Oleh karena itu, pada metode Nagata rekomendasi pembedahan adalah saat usia anak mencapai 10 tahun dan lingkar dada telah mencapai $60 \mathrm{~cm}$ pada daerah taju pedang. Pada serial kasus ini, pembedahan rekonstruksi dilakukan pada pasien berusia 15 dan 17 tahun. ${ }^{9,10}$

Keadaan mikrotia dibagi menjadi 4 klasifikasi, yaitu Derajat I jika telinga luar terlihat normal tetapi sedikit lebih kecil. Derajat II: jika terdapat defisiensi struktur telinga seperti tidak terbentuknya skapa, lobul, heliks atau konka. Derajat III terlihat seperti bentuk kacang tanpa struktur telinga atau anotia. Kelainan ini membutuhkan proses operasi rekonstruksi dua tahap atau lebih. Kelompok ini diklasifikasikan sebagai mikrotia klasik. Derajat IV atau anotia biasanya secara komplit tidak memiliki struktur telinga luar. Pada pemeriksaan fisik kedua telinga di kasus ini didapatkan tampak gambaran klasik deformitas seperti kacang, dan menurut klasifikasi Aguilar dan Jahrsdoefer tergolong mikrotia Derajat III. ${ }^{10-12}$

Kondisi mikrotia biasanya membuat pasien mengalami tekanan, kekhawatiran, dan rendahnya rasa percaya diri. Untuk memperbaikinya diperlukan operasi rekontruksi yang dapat memberikan hasil yang baik dengan cara yang efektif. Hasil operasi yang baik akan memberikan keuntungan pasien secara segi psikologis. ${ }^{14}$ Secara teknis, rekontruksi aurikuloplasti terbagi menjadi 3 metode yang dikembangkan oleh Aguilar, Brent dan Nagata. Pada rekontruksi ini biasanya dilakukan pemilihan kartilago yang elastic dan kulit yang muda untuk menyokong rangka kartilago dan kulit agar mendapatkan hasil yang maksimal. ${ }^{10-13}$

Pada laporan kasus ini, dipilih metode Nagata sebagai prosedur pilihan bagi kedua pasien. Sebelum metode ini dikembangkan prosedur aurikoplasti dilakukan dalam 4 hingga 6 tahap, sedangkan Nagata berhasil melakukan prosedur ini dalam 2 tahap. Dibandingkan dengan kedua teknik lain, metode Nagata lebih menuntut ketepatan dan keahlian dalam pengerjaannya. Prosedur ini memberikan keuntungan untuk pasien karena akan mempercepat waktu rekontruksi yaitu rekonstruksi tahap ke-2 dilakukan 12 minggu setelah tahap $1 .{ }^{10}$

Prosedur tahap 1 yaitu pembentukan framework dengan menggunakan tulang rawan iga ke $6,7,8$ sisi kiri pada pasien pertama dan tulang rawan iga ke 5,6,7,8 pada sisi kanan pada pasien kedua sekaligus mentransposisi lobul. Bila dibandingkan dengan artikel yang ditulis oleh Akira Yamada, lokasi pengambilan iga sama-sama diambil dari sisi ipsilateral. Terdapat sedikit perbedaan teknik dimana disarankan tulang rawan iga yang diambil adalah dari iga ke 6 hingga 9 dengan pertimbangan kebutuhan persediaan tulang rawan untuk rekonstruksi. Penulis menilai perbedaan ini tidak menimbulkan hambatan karena jumlah tulang iga yang diambil untuk tandur tetap mencukupi untuk prosedur aurikuloplasti. .0,11 $^{10}$

Terdapat pula sedikit perbedaan dengan yang dilakukan oleh Liu dkk yaitu menggunakan tulang rawan iga autologus untuk membentuk 2 bingkai telinga dengan pola telinga yang sama. Mereka menggunakan teknik tissue expander agar kulit dapat dipersiapkan sebagai flap dan graft sebagai pelengkap rekonstruksi telinga yang dilakukan melalui 3 tahap. ${ }^{16}$ Teknik rekonstruksi terdiri dari: "perluasan" daerah post aurikula menggunakan tissue expanders bentuk ginjal, membentuk bingkai telinga dari iga 6-8 lalu ditanam dibawah kulit yang telah "diperluas" tadi, dan tahap 3 yaitu mempercantik telinga yang direkonstruksi, membentuk konka agar tampak lebih cekung, rekonstruksi tragus dan pengangkatan sisa telinga yang abnormal. ${ }^{16}$ Pada penelitian yang dilakukan oleh kofi dkk, memodifikasi teknik nagata dan brent rekontruksi telinga tulang rawan yang diimplantasikan di jaringan subkutan pada radial 
arteri. Hal ini dilakukan selama 3 bulan untuk mendapatkan hasil jaringan yang baik karena tervaskularisasi dengan baik dalam mengurangi jaringan parut, kontraktur dan hasil kosmetik yang tidak sesuai. ${ }^{17}$

Dalam pelaksanaannya penggunaan tulang rawan sendiri sangat jarang menyebabkan komplikasi. Namun perlu secara tepat dan adekuat dalam menentukan derajat ketebalan kulit dalam tahap pertama untuk mencegah iskemia pada kulit. Menurut Liu dkk metode rekonstruksi telinga yang paling sering digunakan adalah Brent dan Nagata, dan penggunaan tulang rawan iga autograft sebagai bahan pembentuk bingkai telinga sangat menguntungkan karena mengecilkan angka kejadian infeksi, saat pembentukan bingkai telinga juga lebih mudah, terhindar dari reaksi penolakan tubuh terhadap jaringan asing yang masuk serta toleransi telinga terhadap tekanan jangka panjang yang cukup baik. ${ }^{16}$ Satu yang perlu diperhatikan adalah perlunya kehati-hatian dalam diseksi pengambilan tulang rawan iga karena beresiko untuk terjadinya pneumothorak. ${ }^{12}$ Selain itu menurut kyeong-Tae dan Kap Ssung pada penelitiannya menyebutkan bahwa terdapat beberapa faktor pada rekontruksi telinga yang dapat memberikan hasil tidak maksimal seperti kelainan bawaan yang menyertai keadaan mikrotia seperti hemifacial microsomia, tipe lobul pada klasifikasi mikrotia, dengan rata-rata usia pada penelitian tersbut 15 tahun. Keadaan ini dapat menghambat proses penyembuhan luka dan meningkatkan resiko terjadinya jaringan parut hingga kontraktur. Perlunya skrining awal resiko kelainan bawaan, ketepatan waktu operasi dan persiapan yang baik serta perawatan luka pasca operasi yang tepat dapat membantu memberikan hasil terbaik. ${ }^{18-20}$ Pada penelitian ini, prosedur tandur autologous pada tahap 1 dilakukan dengan sebaik mungkin yang dibuktikan dengan tidak terdapat tanda infeksi, penolakan reaksi tubuh serta komplikasi pada pendengarannya.

Kekurangan pada penelitian ini tidak adanya pemeriksaan untuk meniai kelainan bawaan lainnya, kuesioner mengenai penyembuhan luka. Waktu dalam melakukan skin graft juga cukup lama karena kesulitan dalam menyesuaikan dengan bentuk telinga yang normal. Faktor keahlian dan keterampilan sangat berpengaruh, sehingga diharapkan pada penelitian selanjutnya dilakukan dengan perencanaan dan kesiapan yang lebih baik. Kesimpulan, penggunaan tandur autologus masih mejadi pilihan utama dalam penatalaksaanaan operasi mikrotia karena mengecilkan angka kejadian infeksi dan terhindar dari reaksi penolakan tubuh terhadap jaringan asing yang masuk serta toleransi telinga terhadap tekanan jangka panjang yang cukup baik.
Rekonstruksi telinga mikrotia adalah salah prosedur pembedahan yang paling menantang, namun jika dilakukan dengan baik secara kosmetik akan memuaskan. Perencanaan yang cermat, detail dalam merencakan dan manajemen jaringan konservatif diperlukan untuk mendapatkan hasil yang sangat baik

\section{Daftar Pustaka}

1. Ghanie Irwan A, Sugianto. Teknik Pemeriksaan Kelainan Telinga Hidung Tenggorok, Ed 1. EGC. 2007;(1) 47 - 48,53 -53 .

2. Alasti F, Camp GV. Genetics of microtia and associated syndromes. J Med Genet 2008; 46:361-85

3. Deng K, Dai L, Yi L, et al. Epidemiologic characteristics and time trend in the prevalence of anotia and microtia in China. Birth Defects Res A Clin Mol Teratol 2016;106:88-9

4. Lalwani A.K. Current Diagnosis and Treatment in Otolaringology - Head and Neck Surgery. New York : Mc Graw Hill. 2007.

5. Kryger, Zol B. Mikrotia Repair. In Kryger, ZB. Practical Plastic Surgery. 2005;1

6. Thorne, Charles H. Otoplasty and Ear Reconstruction. Grabb and Smith's Plastic Surgery 6th ed. Philadelphia : Lippincott Williams \& Wilkins. 2007

7. Sarkissian, Raffi der. Otoplasty. In Dolan, $W$ editor. Facial Plastic, Reconstructice, and Trauma Surgery. New York : MarcellDecker. 2005

8. Long, Xiao, et al. Complication rate of autologous cartilage microtia reconstruction: a systematic review. Plastic and reconstructive surgery Global open. 2013; 1(7).

9. Anghinoni M, Bailleul C , Magri AS . Auricular reconstruction of congenital microtia: personal experience in 225 cases. Acta Otorhinolaryngol Ital 2015; $35: 191-7$.

10. Yazdi AK, Hosseini MS, Sadeghi M, Sazgar AA, Safihani R. Comparison of microtia reconstructive with autograft versus homograft. Arch Iranian Med 2007; 10:43-7

11. Yamada A. Autologous Rib Microtia Construction: Nagata Technique. Facial plastic surgery clinics of North America 2018; 26 (1) : 41-55.

12. Yamada A, Ueda K, Harada T. Aesthetic curve analysis of the normal auricle: development of normal ear templates and its clinical application for total auricular reconstruction. J Plast Surg. 2011;54(3):251-9. 
13. Bonilla, A. Pediatric Microtia Reconstruction with Autologous Rib: Personal Experience and Technique with 1000 Pediatric Patients with Microtia. Facial plastic surgery clinics of North America 2018; 26(1): 57-68.

14. Chauha DS, Guruprasad Y. Auricular reconstruction of congenital microtia using autogenous costal cartilage: report of 27 cases. Journal of maxillofacial and oral surgery 2012; 11(1): 47-52.

15. Cui C, Li Y, Zhang R, Zhang Q, et al. Patient Perception and Satisfaction Questionnaire for Microtia Reconstruction: A New Clinical Tool to Improve Patient Outcome. Journal of Craniofacial Surgery 2018; 29(2) : e162-e167.

16. Han SE, Lim SY, Pyon JK, et al. Aesthetic auricular reconstruction with autologous rib cartilage grafts in adult microtia patients. J
Plast Reconstr Aesthet Surg 2015; 68 :10851094

17. Liu X, Zhang Q, Quan Y, Xie Y, Shi L. Bilateral microtia reconstruction. Journal of Plastic, Reconstructive \& Aesthetic Surgery. $2010 ; 63(8): 1275-8$.

18. Boahene, Derek K, Owusu, James A. Advances in microtia reconstruction. Operative Techniques in OtolaryngologyHead and Neck Surgery 2017; 28(2): 133136.

19. Lee, KT, Oh, KS. Predictors for Unfavorable Projection of the Constructed Auricle following Ear Elevation Surgery in Microtia Reconstruction. Plastic and reconstructive surgery 2018;141(4): 993-1001.

20. Janis JE, Harrison B. Wound healing: Part I. Basic science. Plast Reconstr Surg. 2016; 138(Suppl):9S-17S. 